Article

\title{
Can Resilience Thinking Inform Resilience Investments? Learning from Resilience Principles for Disaster Risk Reduction
}

\author{
Margot Hill Clarvis ${ }^{1, *}$, Erin Bohensky ${ }^{2}$ and Masaru Yarime ${ }^{3,4}$
}

1 Institute of Environmental Sciences, University of Geneva, 66 boulevard Carl Vogt, 1205 Geneva, Switzerland

2 Commonwealth Scientific and Industrial Research Organisation (CSIRO), Land and Water Flagship, Australian Tropical Science and Innovation Precinct, Private Mail Bag, Aitkenvale QLD 4814, Australia; E-Mail: Erin.Bohensky@csiro.au

3 Graduate School of Public Policy, University of Tokyo, Hongo 7-3-1, Bunkyo-ku, Tokyo 113-0033, Japan; E-Mail: yarimemasa@gmail.com

4 Department of Science, Technology, Engineering and Public Policy (STEaPP), University College London, Boston House, 36-38 Fitzroy Square, London W1T 6EY, UK

* Author to whom correspondence should be addressed; E-Mail: margot.hill@unige.ch or margot.s.hill@gmail.com; Tel.: +44-7817-865-347.

Academic Editor: Rafael D’Almeida Martins

Received: 17 February 2015 / Accepted: 7 July 2015 / Published: 13 July 2015

\begin{abstract}
As the human and financial costs of natural disasters rise and state finances continue to deplete, increasing attention is being placed on the role of the private sector to support disaster and climate resilience. However, not only is there a recognised lack of private finance to fill this gap, but international institutional and financing bodies tend to prioritise specific reactive response over preparedness and general resilience building. This paper utilises the central tenets of resilience thinking that have emerged from scholarship on social-ecological system resilience as a lens through which to assess investing in disaster risk reduction (DRR) for resilience. It draws on an established framework of resilience principles and examples of resilience investments to explore how resilience principles can actually inform decisions around DRR and resilience investing. It proposes some key lessons for diversifying sources of finance in order to, in turn, enhance "financial resilience". In doing so, it suggests a series of questions to align investments with resilience building, and to better balance the achievement of the resilience principles with financial requirements such as financial diversification and replicability. It argues for a critical look to be taken
\end{abstract}


at how resilience principles, which focus on longer-term systems perspectives, could complement the focus in DRR on critical and immediate stresses.

Keywords: disaster risk reduction; private finance; climate resilience; resilience principles; social-ecological systems

\section{Introduction}

The rising cost of natural disasters (Superstorm Sandy, Typhoon Haiyan, Californian droughts, Australian fires, Thai floods) is considered one of several global trends, along with inter-acting resource pressures, volatile commodity prices and food security, and demographic shifts [1]. Collectively, the accelerated rate and intensity of change lead to growing risks and less insurable risks, demanding a strategy that can adapt to uncertainty and change [2]. Governments and businesses are increasingly recognising the need to better manage and prepare for a range of natural hazards (severe and extreme weather and climate events, droughts, tropical cyclones, floods, landslides, heat waves, fires, extreme precipitation and wind events, that occur globally, with heightened regional vulnerabilities) and disasters (i.e., when lives, livelihoods and infrastructure is destroyed) under increasing conditions of uncertainty [1]. As both the economic impacts of natural disasters grow, and state finances continue to deplete, the risk burden for disaster risk reduction (DRR) is increasingly transferring from the public to the private sector.

There is increasing evidence for how investment in resilience - the ability to withstand perturbation and retain structure and function, to self-organise, and to learn and adapt - can protect development dollars and reduce recovery costs through avoided losses [3-5]. Investing in resilience implies an approach that considers all phases of disaster management, from prevention to recovery [6]. However, focus has remained on disaster and crisis management to strengthen recovery and protect livelihoods, preferencing response over preparedness [7,8]. Over the past 20 years, around USD 13.5 billion has been made available to DRR, yet disaster losses in developing nations have amounted to at the very least USD 862 billion or a third of total international development aid [9]. Yet, for every dollar spent on mitigation and preparedness activities, studies have suggested that between USD 4 and USD 11 in disaster-related economic losses can be prevented [10]. The scale of the financing challenge for DRR is not simply a question of lack of capital, but of how to best incentivise capital allocation to preventative investments relating to environmental sustainability, social vulnerability and climate change. As such, the DRR community needs to "establish appropriate funding models for pre-disaster investments in resilience that could deliver positive net impact on future budget outlays" [11].

Appropriate funding models are dependent on greater clarity as to what resilience means. Recent studies into the uptake of resilience concepts among society and DRR practitioners have shown a focus on enabling "bounce back" to the same ecological or social state, with similar structure and function, as before [6,12]. Such a focus, however, often neglects to consider the state's inherent resilience to withstand disturbance in the first place [12]. Less attention has been given to investing in the systemic and "general" resilience of a more sustainable state $[12,13]$. As momentum accelerates to define the financing architecture and instruments of relevance not only to the UNFCCC process, but also for the 
Sendai Framework for DRR (2015-2030) and the broader post-2015 sustainable development agenda, a stronger incentive must be given to all potential financing partners to invest in "general resilience" [14-16]. This raises a challenging set of questions concerning: how aligned are resilience actions with resilience thinking; how might diversifying sources of finance in itself contribute to resilience? Can resilience principles actually inform decisions around DRR and resilience investing? If so, what key lessons might be relevant for diversifying sources of finance to in turn enhance "financial resilience"? This paper aims to help address some of these broad challenges by utilising established principles of resilience [17] as a framework for assessing ongoing DRR activities and potential future financing instruments across a range of scales.

\section{Background}

\subsection{Framing Resilience}

Resilience science focuses on understanding linked human and natural systems with multiple scales of interaction, referred to as social-ecological systems (SES). Resilience in this context is defined as the ability of a SES to withstand perturbation and still maintain the same structure, function and identity [18]. As such, social-ecological resilience focuses on learning, adaptation and flexibility to avoid undesired transformation [19]. Within the context of disaster resilience, resilience refers to how different actors at various scales in the SES purposefully navigate to a desired state following a disturbance or change. However, we note that what is "desired" is normative; furthermore, systems and communities are often affected by disasters precisely because of an inability to exit a maladaptive "desired" state [12].

Adaptive approaches for resilience management are intended to enhance resilience across multiple temporal and spatial scales, thus keeping the system within a particular configuration or regime that will continue to deliver ecosystem goods and services, or to allow the flexibility to move to a more desirable regime when the existing one is no longer tenable [20]. Since SESs are inherently dominated by cross-scale interactions, resilience management also seeks to avoid boundary mismatches and lock-ins that can increase vulnerability to change at other temporal and spatial scales [21]. In recent years, a distinction has been made between specific and general resilience, which is illustrative for understanding disaster interventions and investment.

Specific resilience is the resilience of a particular aspect of a social-ecological system to a particular kind of disturbance; for example, investing in dam construction may provide a community with specific resilience to flooding, but risks creating a perception of flood-proofing and a resistance to taking other actions to reduce vulnerability [22]. General resilience, by contrast, is the capacity of social-ecological systems to adapt or transform in response to a broad spectrum of unfamiliar, unexpected and extreme shocks [23]. As highlighted in the Sendai Framework, investing in DRR for resilience building equate to both public and private investments in structural and non-structural measures at multiple scales (individual, community, country, region) to save lives and livelihoods, prevent and reduce losses and ensure effective recovery and rehabilitation [14].

In this article, we are broadly concerned with the issue of disaster risk reduction (DRR) and climate resilience (i.e., both climate mitigation and adaptation), and as such will use Disaster and Climate Resilience (DCR) to refer to both climate resilience and disaster risk reduction interventions. Given the 
range and scope of activities that could be comprised by this categorisation, in this paper resilience refers to:

- Resilience of what (and for whom): communities (this can also refer to a constellation of inter-connected communities within a given region, e.g., urban communities).

- Resilience to what: natural hazards that are exacerbated by climate change impacts and can be alleviated through a range of DCR activities (droughts, tropical cyclones, floods, landslides, heat waves, fires, extreme precipitation).

- Resilience interventions: climate adaptation and mitigation activities linked with DRR projects implemented at company, community or municipality level.

- Resilience investment: funding or finance that is provided for implementing resilience interventions.

\subsection{Motivations for and Barriers to Investment in Resilience}

In their review of concepts of agency, capacity, and resilience across human development, well-being, and disasters literature, Brown and Westaway [24] note that development and humanitarian discourses are increasingly incorporating concepts of community resilience and social capital. This can involve the promotion of both resilience building through sustainable development (i.e., avoiding poorly planned development and increased poverty through environmental degradation) and the protection of investments in development (by reducing exposure to natural hazards and climate change) [3].

Often it remains unclear whether or how these resilience building activities at community levels are of commercial relevance to private sector partners with larger financial resources, such as international companies and financial institutions (FIs). Spending on DCR in the private sector more broadly (i.e., larger multi-nationals and medium sized enterprises) has focussed on incorporating risk reduction into business planning and management for specific resilience in relation to distinct shocks, such as addressing weaknesses in urban physical infrastructure, business continuity management for rapid recovery, and supply chain risk exposure [25-27]. However, there is often greater focus on the short term and the system of concern (i.e., a particular supply chain) than on longer term, general resilience and connectivity issues [13]. Longer time scales, unintended consequences and feedbacks between corporate actions and social-economic dynamics at the ground level tend to be less prominently taken into account $[7,26]$.

Beyond enterprise risk management for increased resilience, new pools of private capital will need to be mobilised into ex-ante investments to meet the challenges of DCR given the lack of national finance to effectively tackle resilience building [11]. However, much work remains to clarify how private sector partners and investors could become willing to invest in resilience building activities in line with the expectations of international DRR frameworks [28] and along the full risk-resilience continuum (Figure 1). Focus has so far centred on innovation in financial engineering and alternative financial risk transfer mechanisms [29,30] and partnerships [31] to increase resilience in relation to repair and recovery. Risk-transfer or pooling financial instruments allows for the contractual shifting of risk from one party to another, often an insurer (i.e., micro-insurance, catastrophe bonds, etc.), thus supporting the financial protection of potentially damaged assets in the case of disaster. Instruments such as remittances for supporting recovery and the disbursement of payment reliefs also support repair and recovery [32]. 


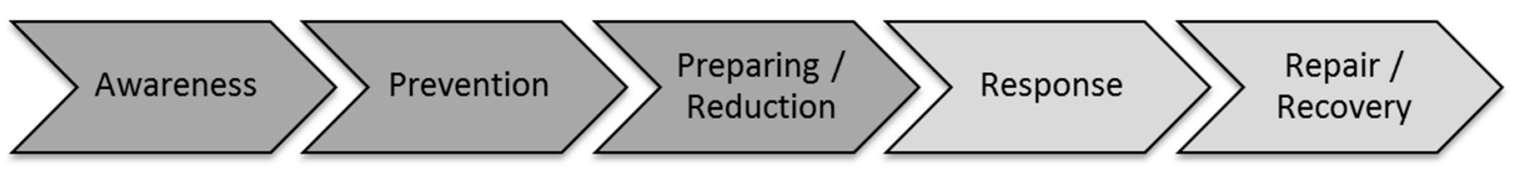

Figure 1. The risk-resilience continuum [32]. Dark grey represents pre-event preparedness activities, while light grey represents post-event response activities.

There has been less focus on how to direct a wider variety of private capital to general resilience building through a broader set of equity and debt instruments, such as micro-credit for alternative livelihoods or payment for ecosystem services (i.e., to retain protective mangroves or forests in place) [33]. There are sizable barriers to investing upfront in DCR activities, not least due to profound uncertainties concerning the probability of rare events, human cognition and complex interactions between human and environmental systems [34,35]. Quantifying the minimisation of losses and demonstrating the benefits versus the costs of financing resilience activities with lengthy upfront investment requirements are both highly complex. Furthermore, it remains a challenge to generate clear cash flows and monetisation of benefits from ecosystem based resilience interventions, while opportunity costs of natural resource revenue streams (e.g., restoring or preserving forests instead of clear-cutting for high value cash crops) remain high [31,36,37]. The lack of understanding of, and access to, suitable potential financing and business partners also remains a barrier [33].

Case evidence of public-private partnerships (PPPs) and collaborations (PPCs) from other studies shows that often the private sector (in these cases comprising of international companies and financial institutions (FIs)) provide in-kind contributions (skills, expertise, training, knowledge transfer, development of tools and information frameworks) [31]. However, the provision of funding can be both rare and small, suggesting that more innovative financing and partnership models are needed to create self-sustaining financing options that could reduce reliance on a selection of donors and enhance the long-term resilience of activities to support the projects [31].

\section{Methodology}

To explore our overarching question about how resilience thinking is informing resilience investments, we use a framework based on seven resilience principles for understanding SES resilience as a lens to assess current programs and activities in the DRR domain [17]. These principles are described below. We then confront this framework with examples of resilience investments at different scales to establish a basis on which private sector engagement, focussing on a set of financial institutions, can be formulated and aligned.

At the local and national scales, we use examples from the International Federation of Red Cross and Red Crescent Societies (IFRC), an international organisation deeply embedded at multiple scales in the financing and support of DCR. Active in 189 countries, through National Red Cross and Red Crescent Societies, IFRC's global coverage and broad portfolio of activities form a significant part of the international effort to enhance DCR. At the global and regional scales, we draw on the recently agreed post-2015 framework for DRR, known as the "Sendai Framework for Disaster Risk Reduction 2015-2030", which sets out the principles, targets and frameworks to reduce disaster losses of lives and assets worldwide [14]. 
Desktop literature review, drawing on Prevention Web, interviews and participation in relevant workshops comprised data collection on the range of resilience interventions encompassing the full range of different types of interventions and practical actions along the risk-resilience continuum [32] that may be relevant for private finance. These activities and the potential institutions and instruments of relevance are then analysed in relation to the resilience principles to understand how resilience principles could better inform resilience investments. A set of questions is developed in order to understand what this might reveal more broadly about investing in resilience, and where resilience interventions could be matched with the requirements and characteristics of a broader range of financial institutions and instruments. Studies that have specifically investigated how investors engage in a range of sustainable land use and social-ecological impact investments were drawn on to help define investment criteria and frameworks including Becker-Birck et al. [31], Huwyler et al. [33], Shames et al. [38], Lai et al. [39] and Bridges Ventures [40].

\section{Are Resilience Principles Aligned with Resilience Investments?}

\subsection{Resilience Principles}

There has been growing guidance on applying "resilience thinking" [41] to practical resource management problems, but there has been far less on how to translate ideas of resilience to guide investment. Over the past decade, a body of research has distilled and proposed key heuristics for understanding and enhancing SES resilience based on theoretical principles and a range of empirical studies [41-43]. Building on this foundation, a systematic assessment identified and thoroughly evaluated the most common propositions for building resilience through a process of literature review, debate, expert survey and further review [17,20]. Emphases of this assessment have included the identification of knowledge gaps, and guidance on how to apply these principles in real-world situations. As noted above, resilience concepts have relevance for framing DRR (e.g., Carpenter et al. [23] and others) but to our knowledge there has been little application of established resilience frameworks, and evaluation thereof, to DRR interventions.

We use the seven principles that emerged from this process as a lens for examining how DCR activities align with "resilience thinking". These principles are:

(1) Maintain diversity and redundancy: Diversity and redundancy provide options for responding to uncertainty and surprise. Systems with many different components (e.g., species, landscape types, knowledge systems or institutions) are generally more resilient than systems with few components. Redundancy provides "insurance" within a system by allowing some components to compensate for the loss or failure of others. Redundancy is even more valuable if the components providing the redundancy are themselves diverse, and thus react differently to disturbance.

(2) Manage connectivity: Connectivity is the structure and strength of ecological and social interactions. High levels of connectivity can facilitate recovery after a disturbance, but can also increase the potential for disturbances (such as disease) to spread across the entire system so that all components of the system are impacted. Connectivity can therefore both enhance and reduce 
the resilience of social-ecological systems and the ecosystem services they produce, and thus needs to be well managed.

(3) Manage slow variables and feedback: SES tend to exist in different configurations of regimes, each of which provides a unique set of ecosystem services. Changes in the underlying slow variables govern shifts in the system from one regime to another (such as when a clear lake becomes polluted). Managing slow variables and feedbacks is often crucial to keep social-ecological systems "configured" and functioning in ways that produce essential ecosystem services that people depend on. Shifts into a different configuration or regime can be extremely difficult to reverse.

(4) Foster complex adaptive systems thinking: Complex adaptive systems (CAS) thinking is a mental model for interpreting the world that appreciates the complexity of SES. Acknowledging that social-ecological systems are based on a complex and unpredictable web of connections and interdependencies is often essential for designing management actions that can foster resilience.

(5) Encourage learning: Because knowledge of SES is always partial and incomplete, learning and experimentation through adaptive and collaborative management is an important mechanism for building resilience in social-ecological systems. Learning ensures that different types and sources of knowledge are valued and considered when developing solutions, and leads to greater willingness to experiment and take risks.

(6) Broaden participation: Participation, or the active engagement of relevant stakeholders in the management and governance process, can support transparency, enable knowledge sharing, build trust, create a shared understanding and uncover perspectives that may not be acquired through other scientific processes. Participation can also promote understanding of system dynamics and facilitate collective action to implement or respond to SES change.

(7) Promote polycentric governance systems: Polycentricity is a governance system comprising multiple autonomous governing bodies, which interact with one another both horizontally and vertically. Collaboration across institutions and scales improves connectivity and learning across scales and cultures. Well-connected governance structures can swiftly deal with change and disturbance because they are addressed by those with the greatest agency and capacity to respond in a particular place and time.

\subsection{Investing in Resilience}

Priority 3 of the Sendai Framework recognises the importance of investing in disaster risk prevention and reduction for resilience [14]. At local and national scales, investing in DRR for resilience building encompasses a range of different activities (Table 1) from enhancing livelihood growth and innovation, developing institutional capacity to prepare for and respond to disasters, developing appropriate early warning systems as well as a range of grey and green infrastructural options [14,44-47]. As stated earlier, research has shown that the majority of resilience investments are currently financed through government budget outlays, international aid, donor financing, trust funds, and to a lesser extent, private sector corporate social responsibility (CSR) partnerships [8,9,30]. 
Table 1. Overview of possible Disaster and Climate Resilience (DCR) interventions at national and local scales [14,44-47].

\begin{tabular}{|c|c|c|}
\hline \multicolumn{2}{|c|}{ Preparedness or Response Stage } & \multirow[b]{2}{*}{$\begin{array}{l}\text { DCR Interventions } \\
\text { Disaster loss accounting systems; building institutional capacity; risk } \\
\text { assessment and identification; early warning and prediction systems; } \\
\text { advocacy, education and awareness raising; climate change } \\
\text { modelling; seasonal climate forecast models; climate change } \\
\text { allowances for structures. }\end{array}$} \\
\hline \multirow{3}{*}{$\begin{array}{l}\text { Reduce } \\
\text { Hazards } \\
\text { and Exposure }\end{array}$} & Awareness & \\
\hline & Prevention & $\begin{array}{l}\text { Land-use planning; catchment \& ecosystem management; } \\
\text { community relocation; contingency planning; hazard zoning \& hot } \\
\text { spot mapping; water demand management and efficiency; rain \& } \\
\text { groundwater harvesting/storage systems; structural and } \\
\text { non-structural flood controls (grey and green, i.e., mangrove } \\
\text { planting, forest \& wetland management); disaster proof livelihoods } \\
\text { against unpredictable disasters and changing climates. }\end{array}$ \\
\hline & Preparing/Reduction & $\begin{array}{l}\text { Preparing evacuation plans; incentive mechanisms for individual } \\
\text { actions to reduce exposure; preparing evacuation plans; improved } \\
\text { agricultural and pastoralist techniques and diversification; strengthen } \\
\text { alternative and resilient livelihoods. }\end{array}$ \\
\hline \multirow{2}{*}{$\begin{array}{c}\text { Respond } \\
\text { and Repair }\end{array}$} & Response & $\begin{array}{l}\text { Establishing branch disaster response teams; tracking displacement } \\
\text { during crises; managing evacuations to reduce impacts of disasters; } \\
\text { evacuation planning; relief supplies. }\end{array}$ \\
\hline & Repair & $\begin{array}{l}\text { Post disaster planning; post-disaster livelihoods support } \\
\text { and recovery. }\end{array}$ \\
\hline
\end{tabular}

The finance sector is comprised of both public (government agencies and international organisations) and private sector (businesses and civil society) institutions that offer both the incentives and means for different activities to be undertaken, with diverse motivations for finance and investment. Modalities of public sector funds often utilise instruments and services such as upfront finance, acceleration capital, concessional loans, certified emissions reductions (CERs), payments for ecosystem services (PES), grants, technical capacity grants, as well as financial advisory and brokering. The private sector tends to use loans, micro-credit, direct investments, equity investments, certified emissions reductions, grants and technical capacity. Figure 2 presents an overview of the broad actor constellation around "resilience investing" and the activities listed represent the range of instruments used within the DCR context $[3,48]$. It details the shift in prioritisation of financial return for private investors, including social and environmental impact investors to the more blended priorities of development finance institutions and governments for enhancing social and environmental benefits. [47]. 


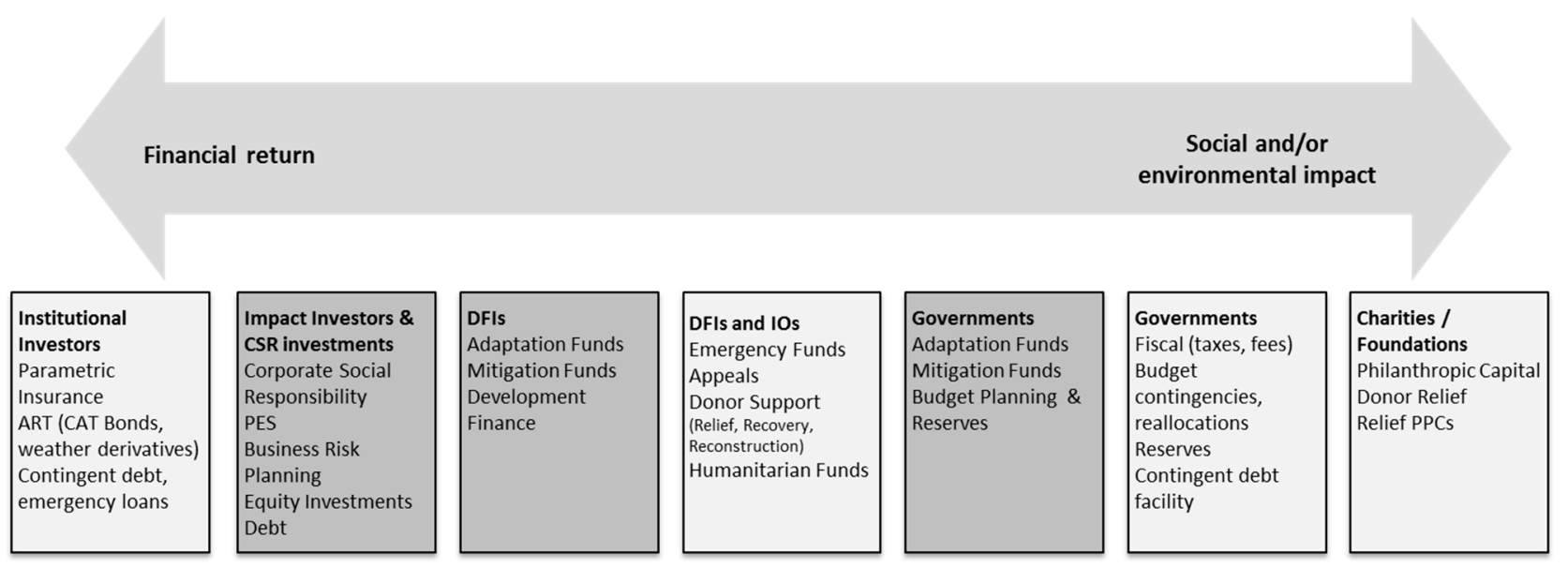

Figure 2. Investor priorities aligned with the range of DCR financing instruments across both private sector (institutional investors, impact investors, non-profit organisations, charitable foundations and CSR spending by businesses) and public sector investors (development finance institutions (DFIs), governments and international organisations) that have been identified as supporting resilience investments [30,48]. Dark grey represents "preparedness" activities, while light grey represents "response" activities as per Figure 1.

\subsection{Applying Resilience Thinking to Resilience Investing}

Table 2 proposes a tentative structure to bring together resilience principles with resilience investing. It attempts to address which forms of financial institution and instrument may adequately meet different sets of requirements that could enable engagement with different activities listed in Table 1. Institutions (as per Figure 2) are listed in order of their position on their ability to finance at different points of commercialisation of a project. In specific regards to the finance sector, there are a range of different investor requirements across different asset classes (i.e., equities, fixed-income, cash equivalents, commodities, real-estate) and financial instruments (loans, equity, investments, risk mitigation, brokering and advisory) [39,40].

The United Nations "Innovative Financing for Development" initiatives suggests that in order to meet the financing needs of sustainable development, all financial flows should be optimised and made use of in a holistic way, including public, private, domestic and international [49]. Table 2 captures and acknowledges the specific characteristics and strengths of different FIs, based on different mandates and underlying incentives, recognising that "maximizing synergies, taking advantage of complementarities, and building on an optimal interplay of all financing sources is essential" [49].

The financing instruments listed therefore represent a wide range of direct and indirect mechanisms, while returns eventually (post-technical assistance grants) may be structured as service payments, compensation fees, offsets, and product sales. Motivations of financing institutions are diverse, representing both internal (revenue generation, asset protection, new services and markets) and external (corporate citizenship, customer vulnerability, enhancing resilience of other clients within that supply chain) incentives [31]. Motivations may range from the desire to diversify returns to the creation of positive social and environmental impact that can serve to support the reduction of risk and costs of infrastructure management, thereby better protecting an investor's or company's assets or fosters increased resilience across a supply shed (i.e., the broader draw area for a particular supply chain). 
Table 2. Financial institutions, instruments, their risk-reward requirements, incentives and motivations, as aligned to the scale and range of DCR activity, drawing on the frameworks of Borsa et al. [50], Huwyler [33] and Becker-Birk et al. [31]. The numbers in the brackets indicate the resilience principle to which they refer (Section 4.1).

\begin{tabular}{|c|c|c|c|c|c|}
\hline \multirow[b]{3}{*}{$\begin{array}{c}\text { Towards } \\
\text { Commercialisation } \\
\text { and Scale }\end{array}$} & Investors & $\begin{array}{l}\text { Risk—Reward } \\
\text { Requirements }\end{array}$ & $\begin{array}{l}\text { Potential Instrume } \\
\text { Options for Resilie }\end{array}$ & $\begin{array}{l}\text { ts and Specific } \\
\text { ce Investments }\end{array}$ & Addressing Resilience Principles and Financing Requirements \\
\hline & $\begin{array}{l}\text { Charities, } \\
\text { Foundations, } \\
\text { NGOs, CSOs }\end{array}$ & $\begin{array}{l}\text { No expectation of } \\
\text { recovery of } \\
\text { principle }\end{array}$ & $\begin{array}{l}\text { - } \text { Grants, } \\
\text { donations } \\
\text { Seed capital } \\
\text { - } \text { Venture } \\
\text { philanthropy } \\
\text { - } \\
\text { Project \& early } \\
\text { stage finance }\end{array}$ & $\begin{array}{l}\text { Technical seed } \\
\text { funding for disaster } \\
\text { action plans in } \\
\text { collaboration with } \\
\text { private sector } \\
\text { investees. }\end{array}$ & $\begin{array}{l}\text { Structure resilience-supporting assets that can be matched with } \\
\text { revenue-generating mechanisms. } \\
\text { - } \quad \text { Do resilience programs embody ideas of adaptive management that } \\
\text { allow trial-and-error approaches? (6) } \\
\text { - Do resilience programs involve and integrate actors and institutions } \\
\text { across scales, so that they match scales of problems and solutions? (7) } \\
\text { - Do they invest in multi-scale governance and multi-scale } \\
\text { resilience-building, and consider how investment at one scale can } \\
\text { flow to others? (7) }\end{array}$ \\
\hline & $\begin{array}{l}\text { Development } \\
\text { Finance } \\
\text { Institutions }\end{array}$ & $\begin{array}{l}\text { - High risk } \\
\text { - } \text { Illiquid } \\
\text { - } \text { Long to } \\
\text { medium term } \\
\text { investment } \\
\text { horizon }\end{array}$ & $\begin{array}{l}\text { - } \text { Risk finance } \\
\text { - } \text { Up-front } \\
\text { finance, seed } \\
\text { capital } \\
\text { - } \\
\text { Project \& early } \\
\text { stage finance }\end{array}$ & $\begin{array}{l}\text { Risk } \\
\text { finance/guarantees } \\
\text { for climate } \\
\text { resilience bonds. }\end{array}$ & $\begin{array}{l}\text { Create general replicable models from individual projects with } \\
\text { multi-stakeholder buy-in to leverage larger scales of investment. } \\
\text { - } \quad \text { Are multiple elements of the system able to respond independently or } \\
\text { perform similar functions? (1) } \\
\text { - } \quad \text { Are resilience activities being designed to be replicable across } \\
\text { different contexts, while also enabling unique rather than "one size } \\
\text { fits all" approaches? (1) } \\
\text { - Has the balance between openness (allowance for re-use, flexibility } \\
\text { and customisation) and modularity (independent programme } \\
\text { components, the containment of disturbance by compartmentalising } \\
\text { different SES system components) been considered? (2) } \\
\text { - Are resilience activities programme focussed, with a systemic view of } \\
\text { interconnections, rather than implemented project by project? (2) }\end{array}$ \\
\hline
\end{tabular}


Table 2. Cont.

\begin{tabular}{|c|c|c|c|c|c|}
\hline & Investors & $\begin{array}{l}\text { Risk-Reward } \\
\text { Requirements }\end{array}$ & $\begin{array}{l}\text { Potential Instrume } \\
\text { Options for Resilie }\end{array}$ & $\begin{array}{l}\text { ts and Specific } \\
\text { ce Investments }\end{array}$ & Addressing Resilience Principles and Financing Requirements \\
\hline & $\begin{array}{l}\text { Investment } \\
\& \text { Asset } \\
\text { Managers }\end{array}$ & $\begin{array}{ll}\text { - } & \text { Medium-high } \\
\text { risk } \\
\text { - } & \text { Medium-term } \\
\text { investment } \\
\text { horizon } \\
\text { - } & \text { Stable returns } \\
& \text { High IRR } \\
& \text { on exit }\end{array}$ & $\begin{array}{l}\text { - } \text { Micro-credit } \\
\text { - Venture capital } \\
\text { - Private Equity } \\
\text { - } \\
\text { Alternative } \\
\text { bonds } \\
\text { (green bonds). }\end{array}$ & $\begin{array}{l}\text { Post disaster credit } \\
\text { schemes: } \\
\text { micro-insurance } \\
\text { funds (i.e., } \\
\text { Alliance Trust). }\end{array}$ & $\begin{array}{l}\text { Monitoring and evaluation frameworks must support the involvement and } \\
\text { integration of actors and institutions across scales, so that they match } \\
\text { scales of problems and solutions. } \\
\text { - Do activities support both physical and social networks and linkages? (2) } \\
\text { - Do they include monitoring and evaluation to assess second-loop (are } \\
\text { we asking the right questions?) and triple-loop learning (how do we } \\
\text { know we are asking the right questions?)? (5) } \\
\text { - Do approaches to resilience enable meaningful consultation and } \\
\text { participation of diverse stakeholders with diverse knowledge in } \\
\text { decision-making, with a view to building common understanding? (7) }\end{array}$ \\
\hline $\begin{array}{c}\text { Towards } \\
\text { Commercialisation } \\
\text { and Scale }\end{array}$ & $\begin{array}{l}\text { Commercial } \\
\text { Banks }\end{array}$ & Low risk & 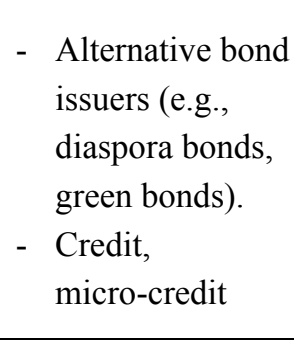 & $\begin{array}{l}\text { Mobile/ICT business } \\
\text { solutions for early } \\
\text { warning programmes. }\end{array}$ & $\begin{array}{l}\text { Give consideration to interlinkages, connectivity and causal relationships } \\
\text { between system drivers to avoid superficial and myopic outcomes that are } \\
\text { harmful in the medium to long term. } \\
\text { - Do resilience activities allow subsets of the system to be insulated so } \\
\text { that shocks cannot spread? (2) } \\
\text { - Are quick-fix responses being implemented that lead to superficial or } \\
\text { harmful outcomes in the long run? (3) }\end{array}$ \\
\hline & $\begin{array}{l}\text { Institutional } \\
\text { Investors } \\
\text { (e.g., } \\
\text { Pension } \\
\text { Funds, } \\
\text { Insurance) }\end{array}$ & 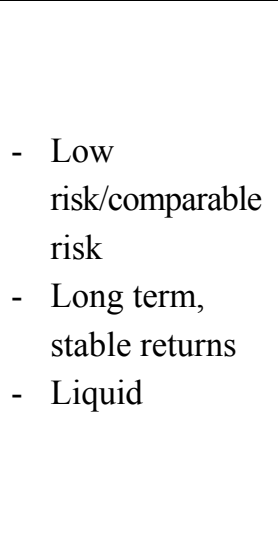 & $\begin{array}{l}\text { - Market } \\
\text { instruments: } \\
\text { alternative bond } \\
\text { offerings (e.g., } \\
\text { green bonds), } \\
\text { equities. } \\
\text { - Securitised } \\
\text { cash flows }\end{array}$ & $\begin{array}{l}\text { Investors in climate } \\
\text { resilience bonds, } \\
\text { green infrastructure. }\end{array}$ & $\begin{array}{l}\text { Match yield and maturity requirements, without taking a reductionist } \\
\text { approach to CAS properties, e.g., recognising high levels of } \\
\text { interconnectedness, potential for non-linear change, and inherent } \\
\text { uncertainty and surprise. } \\
\text { - } \quad \text { Are response strategies also considering rebuilding resilience against } \\
\text { possible future disturbances? (3) } \\
\text { - Do resilience actions/programmes support long-term thinking and } \\
\text { planning processes, including consideration of system drivers and } \\
\text { causal relationships? (3) } \\
\text { - Do resilience activities allow longer-term, systemic issues to be taken } \\
\text { into account? (4) }\end{array}$ \\
\hline
\end{tabular}


In column 4, we propose some potential DCR activities that could match the requirements of a particular investor. In the far right hand column we then pose a series of questions in relation to the principles, which could help practitioners and investors ask whether or not they are designing resilience investments as a short-term objective or a longer-term approach to help shape sustainable practice. The aim is that these questions could serve as a guideline to align resilience principles with financing requirements to ensure fundable activities would indeed support resilience in complex adaptive systems. While all the questions listed are relevant across different institutional contexts, each set of questions has been listed according to the institution of most relevance.

Table 2 unpacks some of the specific actions that investing in DCR might entail as well as the principles that comprise "resilience thinking" to show that resilience thinking can indeed inform resilience investing, particularly in relation to pointing at key blind spots related to single issue thinking, or a focus on a single issue of concern. However, given the many challenges for resilience thinking to better support resilience investing discussed in Section 2.2, greater effort will need to be made to better balance the requirements of the resilience principles with the needs of the finance sector for scalability, predictability, replicability and tradability. For example, commercial banks and investors may prefer relatively low-risk over quite short-term investment, yet by incorporating complex adaptive system thinking into their risk screening, they may avoid negative implications from unintended consequences of not accounting for broader factors that might affect social-ecological resilience. For longer term investors, studies have suggested that financial instruments such as grants, donations, bonds, and 10-12 year private equity investment funds could be made from a long-term perspective and support feedbacks and adaptations in the presence of uncertainties and disturbances, while bonds could still allow for securitised returns [51].

While general resilience requires the ability to be flexible, the majority of DCR activities still tend to focus on developing systems' robustness to isolated shocks, even at the programmatic rather than specific deliverable level. In the often top-down, command-and-control approaches to crisis management in DCR, a critical look should be given to how redundancy, connectivity, learning and feedbacks, and recognition of broader systems issues could complement the focus on critical and immediate stresses, thus addressing more uncertain and chronic long-term stresses.

\subsection{Potential Implications for Scaling Resilience Investments}

Carpenter et al. ([52] p. 3255) recognised that "unless incentives are constructed properly, short-term decision making will tend away from the long-term view that is needed to build and maintain general resilience". Constructing the right incentives and interface for a deeper engagement of private sector stakeholders, the majority of whom (excluding long-term investors such as pension funds, insurance companies, and sovereign wealth funds) tend to be driven by shorter-term timeframes, will be vital to addressing some of the key barriers to long-term thinking currently plaguing many financial institutions $[53,54]$. The United Nations' Study on "Innovative Financing for Development" noted that "different types of finance must be used in a holistic way, as complements rather than substitutes", given the profit- and production orientation of private finance often does not match as well with the less attractive longer-term expected returns on investments associated with sustainable development [49]. A number of studies that have investigated how private sector financers could bring much needed capital 
to a range of challenges concerning improving the resilience of ecological and social systems at a landscape (rather than community, farm, factory scale) suggests that this requires a set of effective conditions [31,33,38,39].

Firstly, diversification is needed whereby projects can be scaled up into investible programmes. This requires a professional management approach that can foster connectivity, sharing of best-practice and rapid replication. Secondly, community business acumen and financial literacy is also required for developing replicable and potentially off the shelf options, which can be applicable to multiple contexts. Thirdly, full transparency of the investment product and its characteristics, including clear information on the expected return and risks associated with the investment, and the required individual investment size and duration of the commitment. There must be a concordant level of understanding between all stakeholders. Fourthly, for smaller upfront investments to ensure scalability of finance, then replicable, programme rather than project focussed business models and activities must be identified. In some instances, activities or loans may need to be bundled into products that could be securitised and traded in financial markets [55]. Other studies have shown the need for liquidity, in terms of a clear ability for investors to sell on the asset at the close of the investment term [38].

Another major challenge will be to move from using resilience thinking to inform a framework for resilience investing to operationalising the activities, instruments and requirements presented in Table 2 into practicable investments on the ground. Of the list of instruments presented in Table 2, a range of alternative bond offerings and structures have recently received a great deal of attention and uptake in financial markets, with demand far outstripping current supply in part due to their ability to aggregate and scale projects into investible assets [56]. Green bonds, forest bonds, and social impact bonds provide useful lessons for packaging programmes and projects in order to attract private investment interest into both low carbon growth and increased climate resilience [15]. There has been increasing focus on how eco-securitisation as part of the bond structure might improve the feasibility of financing "natural infrastructure" and creating a more palatable risk-sharing arrangement by linking sustainable management of natural resources with the funding capacity and requirements of asset-backed securitisation [57]. DFIs (such as the World Bank or the IFC) or national governments could serve as the structuring investor and guarantor, buying down interest rates by purchasing junior or mezzanine tranches (i.e., increased risk levels associated with a subordinated obligation of repayment). This then allows other more mainstream investors (e.g., institutional investors such as pension funds and insurance companies) to buy the senior tranches with more adequate returns and lower risks.

Bonds may be backed by (i.e., ensure investment returns through) a portfolio of community based enterprises producing either savings on public expenditure or revenue generation through a portfolio of resilience supporting cash flows that might supplement more established cash flows (e.g., CERs, PES supplementing certified organic agricultural products, government income, licence fees from natural resources), or even on the repayment of loans (e.g., micro-credit, credit) from local banks. In 2014, the US State of New Jersey launched its own specified "Climate Resilience Banks", the first public infrastructure banks in the US to focus on energy resilience.

However, a less investigated financial innovation is the potential of diaspora finance. Both Israel and India have made long-running and successful attempts at issuing bonds to their diaspora, which have proven attractive even in poor economic periods. Diaspora bonds are a form of government debt specifically targeted to nationals living and working abroad. Sales can be restricted solely to members 
of a particular nationality or opened to all buyers, with nationals receiving a preferential rate [58]. On the other hand, the World Bank estimates that remittances generate three times more money every year than the total global aid budget, projecting that USD 436 billion would be sent overseas in 2014 despite exorbitant transfer fees of up to $29 \%$ in some cases [59]. Further investigation into potentially competitive cost savings on remittances that could re-direct a small percentage towards a diaspora resilience bond is worth further thought.

It is also worth noting that the issuance of diaspora bonds in other countries such as Kenya and Ethiopia have met with limited success, either due to citizen mistrust of the government or of funds being misspent, or indeed of the level of poverty of the diaspora. In such cases, it may be worth exploring the option of creating a risk pool for national level events by launching bonds at a regional level (i.e., East Africa) through an institution like the African Development Bank [58].

\section{Potential Limitations and Conclusions}

The Principles for Sustainable Insurance have called for a shared responsibility and new ways to collaborate in order to develop effective disaster resilience [60]. The central tenets of resilience thinking are gaining currency among the social-ecological research communities involved in DCR. Yet, more concrete case studies to demonstrate the long-run effectiveness of strategies for general resilience are sorely needed for the practitioner community to design and implement concrete policies and actions [23]. Far less work has been focussed on enhancing the robustness of resilience applications to a broader audience that includes those businesses and investors who need to take up an increasingly prominent role in DCR's financing [61]. As the Sendai Framework moves towards implementation, a broader range of financial actors will need a place at the table alongside communities, local governments and business [32,62]. These institutions will be fundamental to unleashing the potential power of the private sector to support DCR programmes with a self-sustaining source of revenue.

In addition to the many challenges related to investing in resilience presented, such an approach as set out in this article may not be suitable across all DCR activities, notably for those focussed on the development of institutional capacity alone. Furthermore, there would be significant limitations of applying an investment focussed framework in fragile and conflict afflicted states, where the enabling environment for investment is too weak, though vulnerability to disaster and climate risk tends to be highest. However, even in more investment friendly contexts, in order to avoid potential pitfalls, structures should be in place for impact measurement (both positive and negative), safe-guards to avoid undermining resilience [48], as well as ensuring appropriate level of risk transfer between public, private and community counterparts.

More fully engaging with private investors requires a clear delineation of the roles and expertise best provided by different partners to not only ensure that capital resources, risks and maturities are aligned [63], but also that public and not for profit partners' skill-sets and expertise are effectively leveraged. Here, tools such as Better Programming Initiative, an impact assessment tool developed by the ICRC, are worth further exploration in relation to the framework proposed in this paper. Fundamentally, efforts need to be made to more deeply and broadly engage the many agencies involved in DCR in understanding what exactly resilience is, why it is a critical concept, and how it is built as well as undermined. 
Resilience building activities call for attention to diversity, redundancy, connectivity, learning, participation, complex adaptive systems thinking and polycentricity. However, in enabling investment to scale the reach of such activities, a balance must be struck and matched to the right financing partners that may require scalability, predictability, replicability and tradability. Conventional approaches may not be sufficient to address these requirements and so innovative financial measures such as alternative bond offerings and diaspora finance should be further explored. While this paper proposes a framework to demonstrate that resilience thinking can indeed better inform resilience investments, far more collaborative research is needed to apply such an approach to the development of practicable investment opportunities. Such projects would need to be structured so as to map onto (either individually or through aggregation) the motivations and requirements of a range of financial institutions. In support of a sound social-ecological framing of resilience, any such work should integrate a broader range of financial actors and opportunities in post-2015 resilience focussed partnerships, in particular the R!SE initiative of PWC and UNISDR.

\section{Acknowledgments}

The authors are grateful to those who contributed their time and effort to be interviewed for this project. The authors would like to thank participants of the Resilience of Business Event at the Resilience Conference 2014 for their insights that informed this article. We thank Michaela Cosijn for constructive comments on the manuscript.

\section{Author Contributions}

Margot Hill Clarvis led the research from design of the research question, engagement of institutions and experts for conducting the research, primary research and analytical tasks and led the initial drafting of the paper. Erin Bohensky was responsible for leading the analysis of the resilience indicators and their application to the research framework. She led the drafting of sections of the paper focused on resilience and resilience indicators and co-developed the paper's analytical framework. Masaru Yarime provided valuable research insights into the analysis and advice relating to the financial instruments section in particular.

\section{Conflicts of Interest}

The authors declare no conflict of interest.

\section{References}

1. Munich, R.E. Natural Catastrophes 2012: Analyses, Assessments, Positions; Münchener Rückversicherungs-Gesellschaft: Münich, Germany, 2013.

2. Everson, M.; Pujadas, J. Introduction to the journal. Avaiable online: http://www.pwc.com/gx/ en/governance-risk-compliance-consulting-services/resilience/publications/introduction-winningwith-risk.jhtml (accessed on 9 July 2015).

3. World Bank. Building Resilience: Integrating Climate and Disaster Risk into Development; World Bank Group: Washington, DC, USA, 2013. 
4. Cabot Venton, C.; Fitzgibbon, C.; Shitarek, T.; Couleter, L.; Dooley, O. The Economics of Early Response and Disaster Resilience: Lessons from Kenya and Ethiopia. Economics of Resilience Final Report; Department for International Development: London, UK, 2012.

5. Kull, D.; Mechler, R.; Hochrainer-Stigler, S. Probabilistic cost-benefit analysis of disaster risk management in a development context. Disasters 2013, 37, 374-400.

6. Aldunce, P.; Beilin, R.; Howden, M.; Handmer, J. Resilience for disaster risk management in a changing climate: Practitioners' frames and practices. Glob. Environ. Chang. 2015, 30, 1-11.

7. Global Facility for Disaster Risk Reduction. Managing Disaster Risks for a Resilient Future: A Strategy for the Global Facility for Disaster Reduction and Recovery 2013-2015; Global Facility for Disaster Risk Reduction: Geneva, Switzerland, 2013.

8. Kellet, J.; Peters, K. Dare to Prepare: Taking Risk Seriously. Financing Emergency Preparedness: From Fighting Crisis to Managing Risk; Overseas Development Institute: London, UK, 2014.

9. Kellet, J.; Caravani, A. Financing Disaster Risk Reduction: A 20 Year Story of International Aid; Overseas Development Agency: London, UK, 2013.

10. WMO. Climate Information for Reducing Disaster Risk; World Meteorological Organization \& United Nations International Strategy for Disaster Reduction: Geneva, Switzerland, 2009.

11. Deloitte. Building Our Nation's Resilience to Natural Disasters; Australian Business Roundtable for Disaster Resilience and Safer Communities \& Deloitte Access Economics: Canberra, Australia, 2013.

12. Leitch, A.M.; Bohensky, E.L. Return to "a new normal": Discourses of resilience to natural disasters in australian newspapers 2006-2010. Glob. Environ. Chang. 2014, 26, 14-26.

13. Hill Clarvis, M.; Schoon, M.L. Business and resilience: Convergence or critical mis-match? Available online: http://rs.resalliance.org/2014/12/09/business-resilience-convergence-or-criticalmismatch/ (accessed on 13 November 2014).

14. UNISDR. Sendai Framework for Disaster Risk Reduction 2015-2030; United Nations Office for Disaster Risk Reduction: Geneva, Switzerland, 2015.

15. WB. Financing for Development Post-2015; World Bank: Washington, DC, USA, 2013.

16. Cui, L.-B.; Zhu, L.; Springmann, M.; Fan, Y. Design and analysis of the green climate fund. J. Syst. Sci. Syst. Eng. 2014, 23, 266-299.

17. Biggs, R.; Schlüter, M.; Schoon, M.L. Principles for Building Resilience: Sustaining Ecosystem Services in Social-Ecological Systems; Cambridge University Press: Cambridge, UK, 2015.

18. Walker, B.; Holling, C.S.; Carpenter, S.R.; Kinzig, A. Resilience, adaptability and transformability in social-ecological systems. Ecol. Soc. 2004, 9, Article 5.

19. Allison, H.E.; Hobbs, R.J. Resilience, adaptive capacity, and the "lock-in trap" of the western australian agricultural region. Ecol. Soc. 2004, 9, Article 3.

20. Biggs, R.; Schlüter, M.; Biggs, D.; Bohensky, E.L.; BurnSilver, S.; Cundill, G.; Dakos, V.; Daw, T.M.; Evans, L.S.; Kotschy, K.; et al. Toward principles for enhancing the resilience of ecosystem services. Annu. Rev. Environ. Resour. 2012, 37, 421-448.

21. Hill, M.; Engle, N.L. Adaptive capacity: Tensions across scales. Environ. Policy Gov. 2013, 23, 177-192.

22. Pittock, J. Dammed if You Do; GWF Discussion Paper 1102; Global Water Forum: Canberra, Australia, 2011. 
23. Carpenter, S.; Arrow, K.; Barrett, S.; Biggs, R.; Brock, W.; Crépin, A.-S.; Engström, G.; Folke, C.; Hughes, T.; Kautsky, N.; et al. General resilience to cope with extreme events. Sustainability 2012, 4, 3248-3259.

24. Brown, K.; Westaway, E. Agency, capacity, and resilience to environmental change: Lessons from human development, well-being, and disasters. Annu. Rev. Environ. Resour. 2011, 36, 321-342.

25. Gledhill, R.; Hamza-Goodacre, D.; Low, L.P. Business-not-as-usual: Tackling the impact of climate change on supply chain risk. Resil. Win. Risk PWC 2013, 2, 15-20.

26. Vassiliadis, C.G.; Goldbach, G. How the strongest supply chains protect what customers cherish most. Avaiable online: http://www.pwc.com/gx/en/governance-risk-compliance-consultingservices/resilience/publications/supply-chains.jhtml (accessed on 9 July 2015).

27. UNISDR. Final Report: The Business Case for Disaster Risk Reduction; The United Nations Office for Disaster Risk Reduction: Suva, Fiji, 2015.

28. PSI. Top Insurers Call for Urgent Action to Reduce Risk from Natural Disasters, Highlight Us $\$ 190$ Billion Annual Losses and Threat to Lives and Livelihoods; United Nations Environment Programme_-Principles for Sustainable Insurance: Geneva, Switzerland, 2015.

29. Michel-Kerjan, E. Harnessing financial innovation to strengthen disaster resilience. Resil. Win. Risk PWC 2013, 2, 8-12.

30. GFDRR. Innovation in Disaster Risk Financing for Developing Countries: Public and Private Contributions; Global Facility for Disaster Reconstruction and Recovery (GFDRR): Washington, DC, USA, 2011.

31. Becker-Birck, C.; Crowe, J.; Lee, J.; Jackson, S. Resilience in Action: Lessons from Public-Private Collaborations around the World; Meister Consultants Group, Inc.: Boston, MA, USA, 2013.

32. PwC. Working Together to Reduce Disaster Risk; PwC and United Nations International Strategy for Disaster Reduction: Geneva, Switzerland, 2013.

33. Huwyler, F.; Käppeli, J.; Serafimova, K.; Swanson, E.; Tobin, J. Conservation Finance: Moving beyond Donor Funding toward an Investor-Driven Approach; Credit Suisse, WWF, McKinsey \& Company: Zurich, Switzerland, 2014.

34. Min, S.-K.; Zhang, X.; Zwiers, F.W.; Hegerl, G.C. Human contribution to more-intense precipitation extremes. Nature 2011, 470, 378-381.

35. Coumou, D.; Rahmstorf, S. A decade of weather extremes. Nat. Clim. Chang. 2012, 2, 491-496.

36. PwC. Stimulating Private Sector Engagement and Investment in Building Disaster Resilience and Climate Change Adaptation: Recommendations for Public Finance Support; PwC and Department for International Development: London, UK, 2013.

37. UNISDR. Post-2015 Framework for Disaster Risk Reduction (HFA2): Report from 2013 Global Platform Consultations; United Nations Office for Disaster Risk Reduction: Geneva, Switzerland, 2013.

38. Shames, S.; Hill Clarvis, M.; Kissinger, G. Financing Strategies for Integrated Landscape Investment; Landscapes for People, Food and Nature: Washington, DC, USA, 2014.

39. Lai, J.; Morgan, W.; Newman, J.; Pomares, R. Evolution of an Impact Portfolio: From Implementation to Results; Sonen Capital \& KL Felicitas Foundation: San Francisco, CA, USA, 2013. 
40. BridgesVentures. Investing for Impact: Case Studies across Asset Classes; Bridges Ventures, Parthenon Group, Global Impact Investing Network: London, UK, 2010.

41. Walker, B.H.; Salt, D. Resilience Thinking: Sustaining Ecosystems and People in a Changing World; Island Press: Washington, DC, USA, 2006.

42. Walker, B.H.; Gunderson, L.H.; Kinzig, A.P.; Folke, C.; Carpenter, S.R.; Schultz, L. A handful of heuristics and some propositions for understanding resilience in social-ecological systems. Ecol. Soc. 2006, 11, Article 13.

43. Anderies, J.M.; Walker, B.H.; Kinzig, A.P. Fifteen weddings and a funeral: Case studies and resilience based management. Ecol. Soc. 2006, 11, Article 21.

44. Bacinoni, B.; Steed, I.; Tolvanen, P.; Hakiziman, T. Pilot Project: Building Sustainable Local Capacity in the Branches of the Burundi Red Cross Society. Available online: https://www.ifrc.org/docs/Evaluations/Evaluations2011/Africa/978-92-9139-180-6\%20Burundievaluation-report.pdf (accessed on 17 November 2011).

45. IFRC. Saving Lives, Changing Minds: Strategy 2020; International Federation of Red Cross and Red Crescent Societies: Geneva, Switzerland, 2010.

46. IFRC. The Road to Resilience: Bridging Relief and Development for a More Sustainable Future. Ifrc Discussion Paper on Resilience; International Federation of Red Cross and Red Crescent Societies: Geneva, Switzerland, 2012.

47. IFRC. Breaking the Waves: Impact Analysis of Coastal Afforestation for Disaster Risk Reduction in Viet Nam; International Federation of Red Cross and Red Crescent Societies: Geneva, Switzerland, 2011.

48. Mitchell, T.; Mechler, R.; Harris, K. Tackling Exposure: Placing Disaster Risk Management at the Heart of National Economic and Fiscal Policy; Climate \& Development Knowledge Network: London, UK, 2012.

49. Douste-Blazy, P. Innovative Financing for Development; United Nations: New York, NY, USA, 2009.

50. Borsa, L.; Frank, P.; Doran, H. How can Resilience Prepare Companies for Environmental and Social Change?; PwC: London, UK, 2013.

51. Kharrazi, A.; Kraines, S.; Hoang, L.; Yarime, M. Advancing quantification methods of sustainability: A critical examination of emergy, exergy, ecological footprint, and ecological information-based approaches. Ecol. Indic. 2014, 37, 81-89.

52. Carpenter, S.R.; Folke, C.; Norström, A.; Olsson, O.; Schultz, L.; Agarwal, B.; Balvanera, P.; Campbell, B.; Castilla, J.C.; Cramer, W.; et al. Program on ecosystem change and society: An international research strategy for integrated social-ecological systems. Environ. Sustain. 2012, $4,1-5$.

53. UNEP Finance Initiative and Global Footprint Network. E-risc: A New Angle on Sovereign Credit Risk; UNEP Finance Initiative and Global Footprint Network: Geneva, Switzerland, 2012.

54. Ang, A.; Andersson, M.; Ithurbide, P.; Haugerud, P.; Orr, A. Sovereign wealth fund governance for a long-term investment horizon. In Long-Term Investing: Optimal Strategy in Short-Term Oriented Markets; Columbia University: New York, NY, USA, 2013. 
55. Huppé, G.A.; Hug Silva, M. Overcoming Barriers to Scale: Institutional Impact Investments in Low-Income and Developing Countries; International Institute for Sustainable Development: Geneva, Switzerland, 2013.

56. CBI. Bonds and Climate Change: The State of the Market in 2014; Climate Bonds Initiative and HSBC: London, UK, 2014.

57. IFC. Forest-Backed Bonds Proof of Concept study. Avaiable online: http://www.ifc.org/wps/wcm/ connect/topics_ext_content/ifc_external_corporate_site/ifc+sustainability/learning+and+adapting/ knowledge+products/publications/publications_report_forestbackedbonds_wci_131957714175 5 (accessed on 9 July 2015).

58. Fatunla, D.M. Diaspora Bonds: New Emerging Market Capital; Mckinsey: New York, NY, USA, 2013.

59. WB. An analysis of trends in the cost of migrants remittance services. Avaiable online: http://documents.worldbank.org/curated/en/2015/03/24336612/analysis-trends-average-total-costmigrant-remittance-services (accessed on 9 July 2015).

60. PSI. Building Disaster-Resilient Communities and Economies; UNEP Finance Initiative and Insurance Group Australia: Geneva, Switzerland, 2014.

61. Whiteman, G.; Walker, B.; Perego, P. Planetary boundaries: Ecological foundations for corporate sustainability. J. Manag. Stud. 2013, 50, 307-336.

62. Mitchell, T. Rethinking the Global Agreement for Disaster Risk Reduction; Climate and Development Knowldege Network: London, UK, 2014.

63. Saltuk, Y. A Portfolio Approach to Impact Investment: A practical Guide to Building, Analyzing and Managing a Portfolio of Impact Investments; J.P. Morgan: New York, NY, USA, 2012.

(C) 2015 by the authors; licensee MDPI, Basel, Switzerland. This article is an open access article distributed under the terms and conditions of the Creative Commons Attribution license (http://creativecommons.org/licenses/by/4.0/). 